SHORT COMMUNICATION

\title{
Single nucleotide polymorphisms from cytochrome $b$ gene as a useful protocol in forensic genetics against the illegal hunting of manatees: Trichechus manatus, Trichechus inunguis, Trichechus senegalensis, and Dugong dugon (Eutheria: Sirenia)
}

\author{
Paula Braga Ferreira'; Rodrigo A. Torres² \& José Eduardo Garcia'1,3 \\ ${ }^{1}$ Centro Acadêmico de Vitória, Universidade Federal de Pernambuco. Rua Alto do Reservatório, Bela Vista, 55608-680 \\ Vitória de Santo Antão, PE, Brazil. \\ 2 Laboratório de Genômica Evolutiva e Ambiental, Departamento de Zoologia, Centro de Ciências Biológicas, Universidade \\ Federal de Pernambuco. Avenida Professor Nelson Chaves, Cidade Universitária, 50670-901 Recife, PE, Brazil. \\ ${ }^{3}$ Corresponding author. E-mail: jegarcia30@gmail.com
}

\begin{abstract}
The identification of mitochondrial DNA polymorphisms is one of the most efficient methods for species differentiation. Genotyping of molecular markers using PCR/RFLP is a reliable, sensitive and inexpensive method for the detection of species specific mutations. The major causes of decline in Sirenia populations are accidental and intentional catches, collisions with boats and habitat loss. The goal of the present study was to identify, in silico, nucleotide mutations in the cytochrome $b$ gene that can be used for the future development of forensic tools capable of using small tissue fragments to discriminate manatee meat from domesticated species meat commonly used as food sources (bovine, ovine, caprine and swine). DNA sequence alignments revealed two polymorphic sites distinguishing the manatee species from domestic species. The present study reinforced the power of cytochrome polymorphisms as powerful markers for species identification, which may be particularly useful for identifying vulnerable/endangered species. The data provided herein also suggest such mtDNA markers as important conservation tools for combating predatory manatee hunting for illegal meat trade in the Americas.
\end{abstract}

KEY WORDS. Bushmeat; forensic markers; overhunting; SNPs.

The hunting of tropical wildlife has historically been conducted for subsistence consumption and for local trade. But current trends in wildlife harvest from across the globe suggest that the volume of extraction of wild game, or "bushmeat", has increased considerably, and many species are in sharp decline due to over exploitation (AlbRechtsen et al. 2007, BennetT et al. 2007, Milner-Gulland et al. 2003, Redford 1992, Eaton et al. 2009). Species identification based on DNA analyses using biological material obtained from illegal hunting has been used in forensic genetics in European and African countries where hunting is prohibited. The identification of mitochondrial DNA polymorphisms is one of the most efficient methods of species differentiation.

Molecular markers such as single nucleotide polymorphisms (SNPs) can be detected using methods such as polymerase chain reaction (PCR)/restriction fragment length polymorphism (RFLP), which are reliable, sensitive and inexpensive. These methods can be used for the detection of species-specific mutations, which enable classification of samples within a molecular taxonomy perspective (Morin et al. 2004, GonZÁlez et al. 2009). Variation within the cytochrome $b$ gene has been found to be one of the most useful genetic markers for species discrimination (Meyer 1994, Palo \& Merilä 2003, Riddle et al. 2003, Yan et al. 2005, TORRES 2006, PARSON et al. 2000). SNPs can be broadly defined as any single base substitution/indel in the genome of an individual (Primmer et al. 2002). The ability to identify wildlife products, whether as processed meat, skins or whole animals, is possible through by the development of DNA sequence databases using a standardized gene fragment (RATNASINGHAM \& Hebert 2007, Ross et al. 2003, EAton et al. 2009).

Given that the prospection of SNPs is still dependent of a prior knowledge of the species genome, AitKen et al. (2004) tested a method to determine the feasibility of using previously published comparative anchor tagged sequences (CATS) in order to find SNPs for mammal species with poorly known genomes. The authors demonstrated that, for most mammals, the targeted locus approach might provide an efficient and costeffective method of discovering SNPs. 
SACKS et al. (2009) established a SNP genotyping assay for detection of genetic variation in coding regions associated with coat-color alleles, phylogenetically basal mitochondrial mutations, sex markers, and non-coding parts of the fox genome. Malisa et al. (2006) described a protocol based on restriction enzyme digestion of PCR amplicons (PCR/RFLP) from a cytochrome $b$ gene fragment that is useful in the identification of 13 wild African species directly affected by illegal hunting. DNA sequences have been used as complementary tools to construct phylogenies, determine population structure and identify species in different conservation programs directed at marine mammals (Baker \& Palumbi 1994, Parsons et al. 2006, Wolf et al. 2007, Gillett et al. 2008).

Sirenia is an order of aquatic, strictly herbivorous mammals divided into two families: Trichechidae, with three species - Trichechus manatus Linnaeus, 1758, Trichechus senegalensis Link, 1795, Trichechus inunguis (Natterer, 1883) -; and Dugongidae, with one extant species - Dugong dugon (Müller, 1776) - and one extinct species - Hydrodamalis gigas (Zimmermann, 1780). The major cause of this extinction was extreme hunting in the 18th century (BERTA et al. 2006). The distribution range of these species is restricted to warm waters in tropical, subtropical and equatorial areas (VIANNA et al. 2006).

According to the Red List of the International Union for the Conservation of Nature (IUCN 2010), all manatee species are considered vulnerable (VU). Moreover, T. manatus, T. inunguis and D. dugon are listed in CITES (Convention of International Trade in Endangered Species of Wild Flora and Fauna) Appendix I and T. senegalensis are listed in CITES Appendix II (Cites 2010). Appendix I lists species that are the most endangered among CITES-listed animals and plants and Appendix II lists species that are not necessarily now threatened with extinction but that may become so unless trade is closely controlled.

The major causes of decline in Sirenia populations are accidental and intentional catches, collisions with boats and habitat loss (Lima et al. 2007). Both Brazilian manatees ( $T$. manatus and T.inunguis) have been exploited by predatory hunting since the $16^{\text {th }}$ century (LUNA et al. 2008). BEST $(1982,1984)$ estimates that between 1935 and 1954, 10,000 Amazon manatees (T. inunguis) were killed yearly.

In the northern Brazilian coast, marine manatees are still essentially captured for meat consumption (LunA et al. 2008). Due to the large sizes of the specimens, hunters also sell part of the meat in order to make some additional money. The leather of the manatees is used as medicine (poultice) in cuts and swelling, and as tea. The fat is used as medicine, as well as being used to maintain and fry the flesh of the manatee (LunA et al. 2008).

Currently, bioinformatics is essential for the manipulation of biological data, when combined with molecular biology tools allows the development of in silico studies involving genetic resources conservation, remodeling phylogenetic, as- sessment of gene dispersal and search of genomic markers (Rossi $\&$ MarTella 2006).

The GenBank, one of the most complete and popular sequence databases, has more than 100 million nucleotide sequences from thousands of species. This enormous quantity of data offers an immense possibility for research and new discoveries. The in silico analysis is an obligatory first step to work with SNP's, mainly when the species studied is rare and endangered. Thus, the goal of the present study was to identify, in silico, nucleotide mutations in the cytochrome $\mathrm{b}$ gene capable to differentiate manatee meat from domestic species meat, commonly used as food sources. For such purposes, complete and partial Cytochrome b sequences from T. manatus, T. inunguis, T. senegalensis, and D. dugon were retrieved from GenBank in FASTA format. A local database was created using these manatee sequences and additional sequences from four domestic species, thereby allowing further comparisons (Tab. I).

Table I. List of species studied, with GenBank Access Number.

\begin{tabular}{ll}
\hline \multicolumn{1}{c}{ Species } & GenBank Access Number \\
\hline Bos indicus & EF061244 \\
Ovis aries & DQ903227 \\
Capra hircus & D84205 \\
Sus scrofa & DU350133 \\
& AB376964 \\
Trichechus manatus & AY830174 \\
& AY965883 \\
AY965884 \\
Trichechus inunguis & AY965885 \\
& AY965886 \\
Trichechus senegalensis & D83050 \\
AY965887 & AY965888 \\
Dugong dugon & AY965889 \\
& AY965890 \\
& AY965880 \\
& AY965881 \\
& AY965882 \\
& U07564 \\
& \\
& \\
&
\end{tabular}

Nucleotide similarities between sequences were identified using the Sequencher 4.8 program (Gene Codes). Sequence alignments were performed with Clustal $\mathrm{W}$ of the BioEdit 6.0.7 pro- 
gram (Hall 1999). Data mining of the alignments and minor adjustments were performed by eye. Nucleotide polymorphisms and restriction enzyme sites were found using the Cleaver software (JARMAN 2006). After this procedure, we used the pDRAW 32 software v. 1.1.106 (ACACLONE 2009) for selection of these enzymes and the generation of virtual gel electrophoresis.

The local database comprised five sequences obtained from T. manatus, four sequences from T. inunguis (615 bp) and seven complete sequences (1140 bp) from domestic animals. The alignments revealed five polymorphic sites distinguishing the manatee species from domestic species. Such SNPs were related to restriction enzyme digestion sites (Tab. II). Two additional sites were capable of differentiating the manatee species (light-gray sites in Tab. II).

A global analysis of the local database was carried out by adding three Cytochrome $\mathrm{b}$ sequences from T. senegalensis and two sequences from $D$. dugon (615 bp). The alignments revealed two polymorphic sites distinguishing all manatee species from domestic species. These SNPs were discriminated by restriction enzyme digestion with BanI and EcoRV (Tab. II). Two additional sites were capable of differentiating part of the manatee species as explained further in the text (light-gray sites in Tab. II). A total of four enzymes were identified as efficient in detecting seven diagnostic SNPs (Tab. II).

Analyzing the virtual gel electrophoresis it was observed that, by using the enzymes BanI and EcoRV, it is possible to distinguish between domestic species and manatees (Fig. 1). To discriminate T. inunguis from T. manatus, T. senegalensis, and $D$. dugon we used the enzyme HpyCH4III that yielded distinct RFLP profiles (Fig. 2). In addition, the enzyme MwoI also diagnosed the manatee species (Fig. 2). It is important to emphasize that this protocol is unable to differentiate between $T$. manatus and T. senegalensis at the cytochrome $\mathrm{b}$ gene.
The present study reinforced the potential use of cytochrome b polymorphisms as powerful markers for species identification, especially in vulnerably endangered species, such as manatees. The data provided herein should be useful as conservation tools for combating predatory manatee hunting for illegal meat trade.

\section{ACKNOWLEDGEMENTS}

Authors acknowledge Fundação de Amparo à Ciência e Tecnologia do Estado de Pernambuco for grants and P.B.F fellowship (Process APQ-0402-2.01/-8 and IBPG-1483-2.01/08), and Conselho Nacional de Desenvolvimento Científico e Tecnológico for R.A.T. fellowship.

\section{LITERATURE CITED}

Acalone. 2009. Pdraw 32 v. 1.1.136. Freeware available online at: http://www.acalone.com [Accessed: 02. VIII. 2009].

Aitken, N.; S. Smith; C. Schwarz \& P.A. Morin. 2004. Single nucleotide polymorphism (SNP) discovery in mammals: a targeted-gene approach. Molecular Ecology 13 (6): 14231431. doi: 10.1111/j.1365-294X.2004.02159.x.

Albrechtsen, L.; D.W. Macdonald; P.J. Johnson; R. Castelo \& J.E. FA. 2007. Faunal loss from bushmeat hunting: empirical evidence and policy implications in Bioko island. Environmental Science and Policy 10 (7-8): 654-667. doi: 10.1016/j.envsci.2007.04.007.

Baker, C.S. \& S.R. Palumbi. 1994. Which Whales Are Hunted? A Molecular Genetic Approach to Monitoring Whaling. Science 265 (5178): 1538-1539.

Bennett, E.L.; E. Blencowe; K. Brandon; D. Brown; R.W. Burn; G. Cowlishaw; G. Davies; H. Dublin; J.E. Fa; E.J. Milner-Gulland;

Table II. Sequence positions of SNPs and diagnostic restriction enzymes. (PS) Polymorphic site related to the cytochrome b complete sequence of $T$. manatus (NC_010302). Dark-gray sites are diagnostic SNPs between domestic species and manatee species. Light-gray sites are diagnostic SNPs between manatee species.

\begin{tabular}{|c|c|c|c|c|c|c|c|c|c|}
\hline Enzymes & PS & B. indicus & O. aries & C. hircus & S. scrofa & T. manatus & T. inunguis & T. senegalensis & D. dugon \\
\hline BsaHI & 219 & G & $A$ & A & $A$ & C & C & - & - \\
\hline BssSI & 606 & A & A & A & A & G & G & - & - \\
\hline $\mathrm{Xcml}$ & 300 & $A$ & A & A & A & $\mathrm{T}$ & $\mathrm{T}$ & - & - \\
\hline Banl & 474 & A & A & $A$ & A & C & C & C & C \\
\hline \multirow[t]{2}{*}{ EcoRV $^{1}$} & 243 & $\mathrm{C}$ & A & C & C & C & C & C & $\mathrm{T}$ \\
\hline & 411 & A & A & A & A & G & G & G & A \\
\hline HpyCH4III² & $367 / 432 / 580$ & $\mathrm{G} / \mathrm{N} / \mathrm{A}$ & $\mathrm{A} / \mathrm{N} / \mathrm{A}$ & $\mathrm{A} / \mathrm{N} / \mathrm{A}$ & $\mathrm{G} / \mathrm{N} / \mathrm{G}$ & $\mathrm{A} / \mathrm{N} / \mathrm{G}$ & $\mathrm{A} / \mathrm{N} / \mathrm{A}$ & $\mathrm{A} / \mathrm{N} / \mathrm{G}$ & $\mathrm{G} / \mathrm{N} / \mathrm{A}$ \\
\hline $\mathrm{Mwol}^{3}$ & $259 / 580$ & $\mathrm{G} / \mathrm{A}$ & $\mathrm{G} / \mathrm{A}$ & $\mathrm{G} / \mathrm{A}$ & $\mathrm{G} / \mathrm{G}$ & $\mathrm{G} / \mathrm{G}$ & $\mathrm{G} / \mathrm{A}$ & $\mathrm{G} / \mathrm{G}$ & $\mathrm{G} / \mathrm{A}$ \\
\hline
\end{tabular}

${ }^{1}$ One restriction site in position 243 only in $D$. dugon and another restriction site in position 411 in $T$. manatus, T. inunguis, and T. senegalensis. ${ }^{2}$ Three restriction sites for $\mathrm{HpyCH} 4 \mathrm{III}$, and the position 580 is useful on discriminating T. manatus and T. senegalensis from $T$. inunguis and $D$. dugon. $\mathrm{N}$ indicates any nucleotide. ${ }^{3}$ Two restriction sites for $\mathrm{Mwol}$ and the position 580 is also useful on discriminating T. manatus and T. senegalensis from $T$. inunguis e $D$. dugon. 


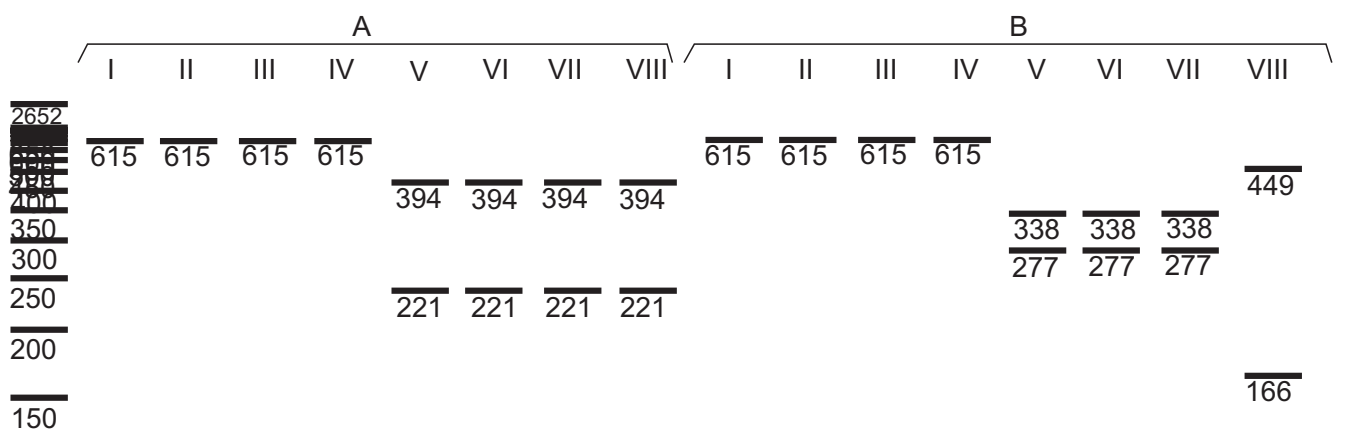

$\overline{100}$

$\overline{50}$

Figure 1. Virtual gel electrophoresis of Cytochrome $b$ RFLP profiles for the four domestic species and for four manatee species under consideration. The Cytochrome b fragment is digested with Banl (394+221bp) (A), EcoRV (338+277bp or 449+166bp) (B) only in the T. inunguis, T. manatus, T. senegalensis and D. dugon. Identification of: (I) Bos indicus Linnaeus, 1758; (II) Capra hircus Linnaeus, 1758; (III) Ovis aries Linnaeus, 1758; (IV) Sus scrofa Linnaeus, 1758; (V) T. inunguis; (VI) T. manatus; (VII) T. senegalensis; (VIII) D. dugon.

A

\begin{tabular}{|c|c|c|c|}
\hline \multicolumn{3}{|c|}{$\mathrm{H}$} & D \\
\hline
\end{tabular}

$\begin{array}{lll}357 & \overline{357} & \\ \overline{258} & \overline{291}\end{array}$

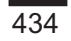

258

$\overline{200}$

$\overline{150} \quad \overline{150}$

$\overline{100}$ $\overline{108}$

$\overline{181} \quad \overline{181} \quad \overline{181} \quad \overline{181}$

$\overline{50}$

Figure 2. Virtual gel electrophoresis of Cytochrome b RFLP profiles for the four manatee species under consideration. The Cytochrome b fragment is digested with HpyCH4III (A) which yields a distinct RFLP profile of 357+150+108bp (T. inunguis) (I) ; 357+258bp (T. manatus and T. senegalensis) (II and III) ; 291+258+66 (D. dugon) (IV). Digestion with Mwol (B) yields distinct RFLP profiles of $434+181 \mathrm{bp}$ (T. inunguis and D. dugon) (I and II), and 321+181+113bp (T. manatus and T. senegalensis) (III and IV). 
J.G. Robinson; J. Marcus Rowcliffe; F.M. Underwood \& D.S. WILKIE. 2007. Hunting for consensus: reconciling bushmeat harvest, conservation, and development policy in west and central Africa. Conservation Biology 21 (3): 884-887. doi: 10.1111/j.1523-1739.2006.00595.x.

BerTa, A.; J.L. Sumich \& K.M. Kovacs. 2006. Marine Mammals: Evolutionary Biology. San Diego, Academic Press, 2nd ed., $547 \mathrm{p}$.

BEST, R.C. 1982. A salvação de uma espécie: Novas perspectivas para o peixe-boi da Amazônia. Revista IBM 14: 1-9.

BEST, R.C. 1984. Trichechus inunguis: Vulgo peixe-boi. Ciência Hoje 2 (10): 66-73.

Cites. 2010. Convention on International Trade in Endangered Species of Wild Fauna and Flora. Appendices I, II and III, available online at: http://www.cites.org. [Accessed: 04.VII.2010].

Eaton, M.J.; G.L. Meyers; S.O. Kolokotronis; M.S. Leslie; A.P. Martin \& G. Aмato. 2009. Barcoding bushmeat: molecular identification of Central African and South American harvested vertebrates. Conservation Genetics 11 (4): 13891404. doi: 10.1007/s10592-009-9967-0.

GilletT, R.M.; B.N. White \& R.M. Rolland. 2008. Quantification and genetic profiling of DNA isolated from free-floating feces of the North Atlantic right whale (Eubalaena glacialis). Marine Mammal Science 24 (2): 341-355. doi: 10.1111/j.1748-7692.2008.00192.x.

González, S.; J.E. Maldonado; J. Ortega; A.C. Talarico; L. Bidegaray-Batista; J.E. Garcia \& M.B. Duarte. 2009. Identification of the endangered small red brocket deer (Mazama bororo) using noninvasive genetic techniques (Mammalia; Cervidae). Molecular Ecology Resources 9: 754-758. doi: 10.1111/j.1755-0998.2008.02390.x.

HaLL, T.A. 1999. Bioedit: a user-friendly biological sequence alignment editor and analysis program for Windows 95/98/ NT. Nucleic Acids Symposium Series 41: 95-98.

IUCN. 2010. Red List of Threatened Species. World Conservation Union, available online at: http://www.iucnredlist.org [Accessed: 04.VII.2010].

JARMAN, S.N. 2006. Cleaver: software for identifying taxon specific restriction endonuclease recognition sites. Bioinformatics 22 (17): 2160-2161. doi: 10.1093/ bioinformatics/btl330.

Lima, R.P.; C.M.C. Alvite \& J.E. Vergara-Parente. 2007. Protocolo de Reintrodução de Peixes-bois marinhos no Brasil. Brasília, Ibama, 62p.

Luna, F.O.; J.P. Araújo; R.P. Lima; M.M. Pessanha; R.J. Soavinski \& J.Z.O. Passavante. 2008. Captura e utilização do peixe-boi marinho (Trichechus manatus manatus) no litoral Norte do Brasil. Biotemas 21 (1): 115-123.

Malisa, A.L.; P. Gwakisa; S. Balthazary; S.K. Wasser \& B.M. Mutayoba. 2006. The potential of mitochondrial DNA markers and polymerase chain reaction-restriction fragment length polymorphism for domestic and wild species identification. African Journal of Biotechnology 5 (18): 1588-1593.

Meyer, A. 1994. Shortcomings of the cytochrome $b$ gene as a molecular marker. Trends in Ecology and Evollution 9: 278-280.

Milner-Gulland E.J.; E.L. Bennett \& The SCB 2002 Annual Meeting Wild Meat Group. 2003. Wild meat: the bigger picture. Trends in Ecology \& Evolution 18 (7): 351-357. doi:10.1016/ S0169-5347(03)00123-X.

Morin, P.A.; G. LUIKART; R. K. WAYNE \& the SNP workshop group. 2004. SNPs in ecology, evolution and conservation. Trends in Ecology and Evolution 19 (4): 208-216. doi:10.1016/ j.tree.2004.01.009

Palo, J.U. \& J. Merilä. 2003 A simple RFLP method for identi.cation of two ranid frogs. Conservation Genetics 4: 801803.

Parson, W.; K. Pegoraro; H. Niederstätter; M. Föger \& M. Steinlechner. 2000. Species identification by means of the cytochrome $b$ gene. International Journal of Legal Medicine 114: 23-28.

Parsons, K.M.; J.W. Durban; D.E. Claridge; D.L. Herzing; K.C. Balcomb \& L.R. Noble. 2006. Population genetic structure of coastal bottlenose dolphins (Tursiops truncatus) in the northern bahamas. Marine Mammal Science 22 (2): 276298. doi: 10.1111/j.1748-7692.2006.00019.x.

Primmer, C.R.; T. Borge; J. Lindell \& G.-P. Saetre. 2002. Singlenucleotide polymorphism characterization in species with limited available sequence information: high nucleotide diversity revealed in the avian genome. Molecular Ecology 11 (3): 603-612. doi: 10.1046/j.0962-1083.2001.01452.x.

Ratnasingham, S. \& P.D.N. Hebert. 2007. The Barcode of Life Data System. Molecular Ecology Notes 7 (3): 355-364. doi: 10.1111/j.1471-8286.2007.01678.x.

REDFord, K.H. 1992. The empty forest. Bioscience 42 (6): 412422.

Riddle, A.E.; K.L Pilgrim; L.S. Mills; K.S. McKelvey \& L.F. Ruggieiro. 2003. Identification of mustelids using mitochondrial DNA and non-invasive sampling. Conservation Genetics 4: 241243.

Ross, H.A.; G.M. Lento; M.L. Dalebout; M. Goode; G. Ewing; P. Mclaren; A.G. Rodrigo; S. Lavery \& C. S. Baker. 2003. DNA Surveillance: Web-Based Molecular Identification of Whales, Dolphins, and Porpoises. Journal of Heredity 94 (2): 111114. doi: 10.1093/jhered/esg027.

Rossi, F.H.J. \& M.B. Martella. 2006. DNA test to sex the lesser rhea (Rhea pennata pennata). British Poultry Science 47: 375-377.

SACKS, B.N.; D.I. VÅge \& M.J. Statham. 2009. A mediumthroughput SNP assay for detecting genetic variation in coding and non-coding portions of the red fox genome. Conservation Genetics Resources 1 (1): 459-463. doi: 10.1007/s12686-009-9106-8.

Torres, R.A. 2006. Molecular taxonomy of Plagioscion Heckel 
(Perciformes, Sciaenidae) and evidence from mtDNA RFLP markers for an invasive species in the Paraná river, Southern Brazil. Revista Brasileira de Zoologia 23 (4): 1235-1242.

Vianna, J.A.; R.K. Bonde; S. Caballero; J.P. Giraldo; R.P. Lima; A. Clark; M. Marmontel; B. Morales-Vela; M.J. de Souza; L. Parr; M.A. Rodríguez-Lopez; A.A. Mignucci-Giannoni; J.A. Powell \& F.R. SAntos. 2006. Phylogeography, phylogeny and hybridization in trichechid sirenians: implications

for manatee conservation. Molecular Ecology 15 (2): 433-447. doi: 10.1111/j.1365-294X.2005.02771.x
Wolf, J.B.; D. Tautz \& F. Trillmich. 2007. Galápagos and Californian sea lions are separate species: Genetic analysis of the genus Zalophus and its implications for conservation management. Frontiers in Zoology 4: 20. doi: 10.1186/ 1742-9994-4-20.

YAN, P.; X-B. WU; Y. SHI; C.M. Gu; R.P. WANG \& C.L. WANG. 2005. Identification of Chinese alligators (Alligator sinensis) meat by diagnostic PCR of the mitochondrial cytochrome $b$ gene. Biological Conservation 121: 45-51. doi:10.1016/ j.biocon.2004.04.008.

Submitted: 05.V.2010; Accepted: 30.XII.2010.

Editorial responsibility: Lorenzo R.S. Zanette 